\title{
EFFECT OF CURRENT RATIO AND DEBT TO EQUITY RATIO ON STOCK PRICES ON REGISTERED METAL AND SIMILAR COMPANIES ON THE INDONESIA STOCK EXCHANGE
}

\author{
Ihsan Rambe ${ }^{1}$, Nurwahyuni ${ }^{2}$, Jasman Saripuddin Hasibuan ${ }^{3}$ \\ 1,2,3 Universitas Muhammadiyah Sumatra Utara \\ Correspondence E-mail: ${ }^{1)}$ ihsanrambe @umsu.ac.id
}

\begin{abstract}
The stock price is the price that occurs in the stock market at a certain time and the stock price is determined by market participants. The high and low price of these shares is determined by the demand and supply of these shares in the capital market. Current Ratio is a ratio to measure the company's ability to pay its long-term debt approach which is due immediately when billed in its entirety. and Debt to Equity Ratio is a ratio that shows the percentage of provision of funds by shareholders to lenders. The higher the ratio, the lower the company's funding provided by shareholders. This study aims to determine whether there is an effect of Current Ratio and Debt to Equity Ratio on stock prices either partially or simultaneously. This study uses financial management theory related to the variables of stock price, current ratio, debt to equity ratio. The approach used is an associative approach. The population in this study are Metal \& Similar companies listed on the IDX for the period 2014-2018. Samples were taken using purposive sampling method, in order to obtain 6 companies as samples. The results show that: (1) the effect of the current ratio on stock prices has no effect; (2) the effect of Debt to Equity Ratio on stock prices has an effect; (3) the influence of the Current Ratio and Debt to Equity Ratio on stock prices simultaneously has an effect.
\end{abstract}

Keywords: Current Ratio, Debt to Equity Ratio and Stock Price.

\section{INTRODUCTION}

The capital market in Indonesia is growing rapidly, this can be seen by the increasing number of shares traded and the higher the trading volume of shares on the Indonesia Stock Exchange. The capital market can be seen as an effective medium in the development of a country, this is possible because the capital market can be used as a tool to raise long-term funds from investors and even from the public which can then be channeled for the development of a country.

The stock price is one indicator of the success of the company's management and is strongly influenced by market forces itself, the stock price is changing or fluctuating at any time and always has ups and downs depending on the amount of supply and demand for shares in principle, the better the company's performance in generating a profit., it will increase the demand for the company's shares, so it will increase the share price itself.

The stock price has its own important value for the company, if the stock price of a company is high this provides an opportunity for the company to get additional investment from investors from the increase in its share price. For investors, if the stock price of a company continues to increase, investors will conclude that the company is performing well(Princess, 2015)

Current Ratio is the ratio between current assets and current liabilities(Rambe et al., 2017). Current Ratio according to (Cashmere, 2014) state that:"Current Ratio (current ratio) is a ratio to measure the company's ability to pay short-term obligations or debts that are due immediately when they are billed in their entirety. In other words, how much current assets are available to cover short-term obligations that are due soon. The current ratio can also be said as a form to measure the level of security (margin of safety) of a company. 
Debt to Equity Ratioshows the greater the total debt to total equity, it will also show the greater the company's dependence on outside parties so that the company's risk level is greater. This will have an impact on decreasing stock prices on the stock exchange so that profits will decrease(Raha, 2010). Debt to Equtity Ratio is "the ratio used to assess debt to equity".

\section{LITERATURE REVIEW}

\subsection{Stock price}

The share price is the price that occurs in the stock market at a certain time and the share price is determined by market participants. The high and low prices of these shares are determined by the demand and supply of these shares in the capital market(Siregar and Pharisees, 2018)

According to Baridwan (2010)Share Price is "the price of shares that occur on the stock exchange at a certain time determined by market participants". The market value is determined by the demand and supply of the shares concerned in the stock exchange market.

The stock price that has increased has a good impact on the company because it can increase the value of the stock otherwise it will have a bad impact on the company's capital because the capital will not increase, it will not increase and will stop because the stock does not sell and many investors want to sell their shares. (Asmirantho and Yuliawati, 2015)

according to Cashmere (2014) The main objectives of investors in the capital market are as follows:

a. Earn dividends

The investor's goal is only aimed at the profits that will be obtained in the form of interest paid by the issuer in the form of dividends.

b. Company ownership

In this case, the investor's goal is to control the company. The more shares owned, the greater the company's business.

c. Trade

According to Fahmi (2015) states that the benefit of the share price for the party who owns it will obtain several benefits as a form of obligation that must be accepted, namely:

1) Obtain dividends to be given at the end of each year.

2) Obtaining capital gains, namely profits when the shares owned are resold at a higher price.

3) Have voting rights for common stock holders.

The high and low share price of a company is influenced by various internal and external factors of the company. The factors are as follows: 1) Macro and micro economic conditions; 2) Company policy in deciding to expand (business expansion), such as opening branch offices (brand offices) and sub-brand offices, both domestically and abroad; 3) Change of directors suddenly; 4) There are directors or commissioners of companies involved in criminal acts and the case goes to court; 5) The company's performance continues to decline over time; 6) Systematic risk, which is a form of risk that occurs as a whole and has contributed to causing the company to be involved; (Princess, 2015).

\subsection{Current Ratio}

Current Ratio is the ratio between current assets and current liabilities(Rambe et al., 2017). Current Ratio as a measure of the company's ability to meet its short-term debt (maturity less than one year) using current assets. Current Ratio is one of the ratios to measure the liquidity ratio(Arseto and Jufrizen, 2018)

The current ratio shows the extent to which current assets cover current liabilities. The greater the ratio of current assets and current liabilities, the higher the company's ability to cover its short-term liabilities. This ratio can be in the form of a number of times or in the form of a percentage. If the current ratio is $1: 1$ or $100 \%$, it means that current assets can cover all current 
liabilities. A low current ratio is usually considered to indicate a problem in liquidation, on the other hand a current ratio that is too high is also not good, because it shows a large number of idle funds which in turn can reduce the company's profitability.(Hantono, 2015)

This ratio has a purpose that is used to measure the ability of a company to pay the company's debt in paying its current debt that will mature when billed in its entirety.Current Ratio can also be regarded as a tool to measure the level of security margin (margin of safety) of a company.

If Current Ratio If a company is low or below industry standards, then the company is experiencing liquidation problems. If a company has a current ratio that is too high, it is also not good(Liquidity Ratio, 2020).

Current Ratio is a ratio that has a very important benefit to measure the company's ability. Especially in terms of paying off its short-term obligations. Which can be known to what extent the actual amount of current assets of the company can guarantee its current debt. If the ratio is higher, the company's debts to creditors will be guaranteed. This ratio is also used to measure the company's ability to pay in the short term. Which will use the current assets owned.(Admin, 2020).

\subsection{Debt to Equity Ratiol}

Debt to Equity Ratio is the "ratio used to value debt to equity". This ratio is sought by comparing all debt, including current debt with all equity. This ratio is useful for knowing the amount of funds provided by the borrower (creditor) with the owner of the company. Debt to Equity (DER) describes the extent to which owner's capital can cover debts to outsiders. This ratio is also called the Leverage ratio(Harahap, 2010)

Here are the goals of the Debt to Equity Ratio (DER) according to Kasmir (2012, p. 153) in the journal (Hasibuan, 2017) :

1. To find out the company's position towards obligations to other parties.

2. To assess the company's ability to meet the fixed.

3. To assess the balance between the value of assets, especially fixed assets with capital.

4. To assess how much the company's assets are financed by debt.

Meanwhile the benefits Debt to Equity Ratio (DER) according to Kasmir (2012, p. 153) in the journal (Hasibuan, 2017) :

1. To analyze the ability of the company's position towards obligations to other parties.

2. To analyze the company's ability to meet fixed obligations.

3. To analyze the balance between value and fixed assets with capital.

4. To analyze how much the company's assets are financed by debt.

\section{IMPLEMENTATION METHOD}

The research method used by the author is an associative approach. The population in this study isMetal \& Similar companies listed on the Indonesia Stock Exchange (IDX) during the period 2014 to 2018 were 17 companies. The data collection technique used in this study will be processed using Microsoft Excel, Eviews 9 and using the documentation method which is carried out by collecting financial report data obtained from the Annual Report which is accessed fromwww.idx.co.id and collect from the data obtained books, journals, theses, news.

\section{RESULTS AND DISCUSSION \\ 4.1 RESULTS} Views 9

Data analysis in this study is included in path analysis. Data analysis technique using E-

\subsubsection{Descriptive statistics}

Descriptive statistical analysis was used to provide an overview of the data used. Table I.1 shows the descriptive statistics of each variable used in the study in the form of independent 
variables, namely the current ratio (CR) and debt to equity ratio (DER).and the dependent variable, namely the stock price (PER). The research variables were interpreted in terms of mean, median, maximum, minimum values. The number of observations in the study is 30 data which is data from metal companies and the like whichlisted on the Indonesia Stock Exchange. The results of descriptive statistical analysis are presented in the following table:

Table 4.1 Descriptive Statistics

\begin{tabular}{|l|r|r|r|}
\hline & \multicolumn{1}{|c|}{ PER } & CR & \multicolumn{1}{c|}{ DER } \\
\hline Mean & 12.11447 & 2.920933 & 1.373933 \\
\hline Median & 8.033000 & 2.296500 & 0.508500 \\
\hline Maximum & 99.30600 & 8089000 & 5.152000 \\
\hline Minimum & -60.59600 & 0.778000 & 0.187000 \\
\hline Std. Dev. & 25.98527 & 1.939654 & 1.585664 \\
\hline Observations & 30 & 30 & 30 \\
\hline $\begin{array}{l}\text { Notes : PER = share price; CR =Current ratio; DER = Debt to } \\
\text { equity ratio }\end{array}$
\end{tabular}

Source: Data processed with eviews 10, 2020

Based on the table above, the statistical analysis of each variable is as follows:

a. The dependent variable is stock price (PER)

The highest share price of 99,306 owned by PT Lion Metal Works Tbk in 2014 and stock price lowest by -60.596 owned by PT Gunawan Dianjaya Steel Tbk in 2014. Variable mean and median values share price of 12,114 and 8,033. Scorestandard deviation of the variable stock priceas big as 25,985 .

b. Independent variable current ratio (CR)

Current ratio has the highest value of 8.089 percent owned by PT Lionmesh Prima Tbk in 2015 and current ratio the lowest of 0.778 percent is owned by PT Gunawan Dianjaya Steel Tbk in 2018. The mean (mean) and mediancurrent ratio as big as 2,921 percent and2,297 percent. The standard deviation of the variablecurrent ratio as big as 1,940 percent.

c. Independent variable debt to equity ratio (DER)

Debt to equity ratio has the highest value of 5.152 percent owned by PT Indal Aluminum Indonesia Tbk in 2014 and debt to equity ratio the lowest of 0.187 percent is owned by PT Beton Jaya Manunggal Tbk in 2017. The mean (mean) and mediandebt to equity ratio as big as 1.374 percentand 0.509 percent. The standard deviation of the variabledebt to equity ratio as big as 1.586 percent.

\subsubsection{Multiple Regression Analysis}

Connection independent variablecurrent ratio $(\mathrm{CR})$ and debt to equity ratio (DER) to the stock price variable (PER) analyzed using multiple regression analysis which is supported by using eviews 10 software. The results of the equation estimation that have been carried out are presented in the following table:

\begin{tabular}{lcccc} 
Variable & \multicolumn{2}{c}{ Table 4.2 Multiple Regression Results } \\
Coefficient & Std. Error & t-Statistic & \multirow{2}{*}{ Prob. } \\
\hline \hline C & $\mathbf{0 . 0 1 4 5 9 6}$ & 0.037623 & 0.387963 & 0.7011 \\
CR & $\mathbf{0 . 0 0 9 6 0 7}$ & 0.008677 & 1.107223 & 0.2780 \\
DER & $\mathbf{0 . 0 3 2 8 5 2}$ & 0.010614 & 3.095135 & 0.0045 \\
Source: Data processed with eviews & 10,2020 & &
\end{tabular}

Based on the results of the regression that has been carried out, the equation model can be formulated as follows: 


$$
\mathrm{HS}=0.014596+0.009607 \mathrm{CR}+0.032852 \mathrm{DER}
$$

The regression results above can be concluded that:

a. Constant a is equal to 0.014596 it means that if the independent variable current rati (CR) and debt to equity ratio (DER) $=0$ (no change), then the dependent variable is stock price (PER) have value as big as 0.014596 .

b. Independent variable current ratio has a correlation coefficient value of 0.009607 shows a positive direction. This means that if the independent variable current ratio increased by 1 unit while the independent variable debt to equity ratio is fixed, the dependent variable is stock price will increase by 0.009607 .

c. Independent variable debt to equity ratio has a coefficient value as big as 0.032852 indicates a positive direction. This means that if the variabledebt to equity ratio increased by 1 unit while the independent variable current ratio is fixed, then the dependent variable is stock price will increase by 0.032852 .

\subsubsection{Classic assumption test}

\section{Normality test}

The normality test aims to test whether in the regression model the confounding or residual variables have a normal distribution or not. The normality assumption test was carried out using the Jarque-Bera test.The criteria for testing carried out are:

a. The data are normally distributed, if score Probability of JB (Jarque-Bera) count > alpha level 0.05 or

b. The data is not normally distributed, if score Probability of JB (Jarque-Bera) count $<$ alpha level 0.05

The results of testing the classical assumption of normality in this study can be seen in the following figure:

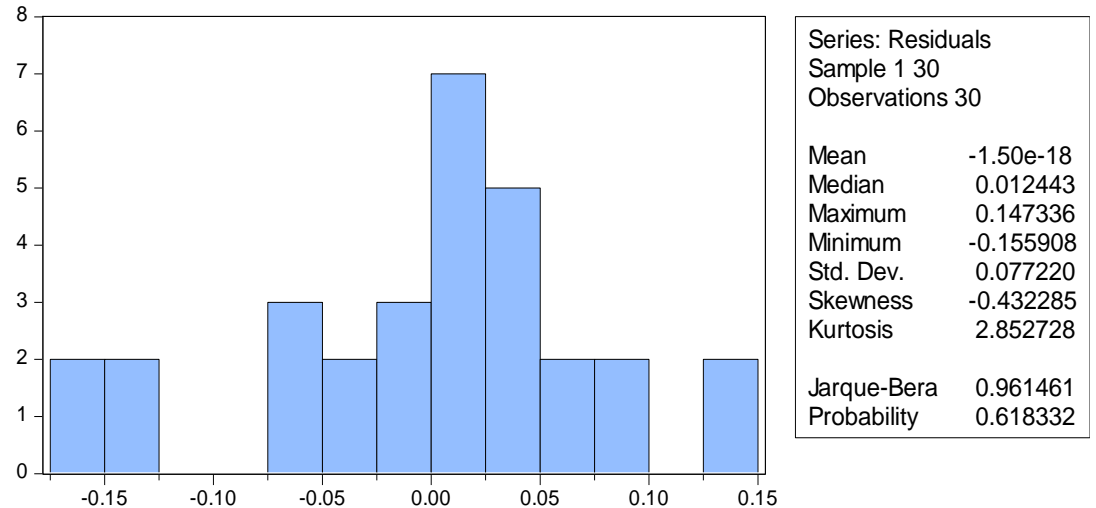

Source: Data processed with eviews 10, 2020

Figure 4.1 Normality Test

Based on the picture above, the value of Prob. JB count $0.618332>0.05$ so it can be concluded that the data has been normally distributed, which means that the classical assumptions about normality have been met.

\section{Autocorrelation Test}

Autocorrelation test is used to test whether in a linear regression model there is a correlation between the confounding error (residual) in period $t$ with errors in period $t-1$ (previous). In this study, to see whether there is an autocorrelation disease, the Langrange Multiplier (LM Test) test 
Effect Of Current Ratio And Debt To Equity Ratio On Stock Prices On Registered Metal And Similar Companies On The Indonesia Stock Exchange

DOI: $10.54443 /$ ijebas.v1i2.77

can also be used by comparing the $\mathrm{R}$-squared probability with $=0.05$. The criteria for testing carried out are:

a. Data there is no autocorrelation problem, if the value ofProb.Obs*R-squared $>0.05$ alpha alpha level or

b. Data experiencing autocorrelation problems, if the value ofProb.Obs*R-squared $<$ alpha level 0.05 .

The results of the autocorrelation test can be seen in the table below:

Table 4.3 Autocorrelation Test Results

Breusch-Godfrey Serial Correlation LM Test:

\begin{tabular}{llll}
\hline \hline F-statistics & 0.635453 & Prob. F(2.25) & 0.5380 \\
Obs*R-squared & 1.451308 & Prob. Chi-Square(2) & $\mathbf{0 . 4 8 4 0}$
\end{tabular}

Source: Data processed with eviews 10, 2020

The LM test results show that the value of prob.obs*r-squared of $0.4840>0.05$, so it can be concluded that the data in this study did not have autocorrelation problems.

\section{Heteroscedasticity Test}

Heteroscedasticity test is used to determine if the variance is not constant and there is a strong relationship between the residuals. To test heteroscedasticity in this study using statistical methods with test White. The criteria for testing carried out are:

a. Data there is no heteroscedasticity problem, if the value ofProb.Obs*R-squared $>0.05$ alpha alpha level or

b. Data experiencing heteroscedasticity problems, if the value ofProb.Obs*R-squared $<$ alpha level 0.05 .

The results of the heteroscedasticity test can be seen in the table below:

Table 4.4 Heteroscedasticity Test Results

Heteroskedasticity Test: White

\begin{tabular}{lclc}
\hline \hline F-statistics & 1.450502 & Prob. F(5,24) & 0.2427 \\
Obs*R-squared & 6.961851 & Prob. Chi-Square(5) & $\mathbf{0 . 2 2 3 5}$ \\
Scaled explained SS & 5.223858 & Prob. Chi-Square(5) & 0.3892 \\
Source: Data processed with eviews & 10, 2020
\end{tabular}

Test results heteroscedasticity above shows that the value of prob.obs*r-squared has a value of > alpha 0.05 , which is 0.2235 , so it can be concluded that the regression model in this study did not experience heteroscedasticity problems.

\section{Multicollinearity Test}

Testi Multicollinearity needs to be carried out on regressions that use more than one independent variable, this is to find out whether there is a mutually influencing relationship between the independent variables studied. The criteria for testing carried out are:

a. Data there is no multicollinearity, if the coefficient value $<0.85$ or

b. Data experiencing multicollinearity, if the coefficient value $>0.85$

The correlation coefficient in this study can be seen in the table below.

Table 4.5 Multicollinearity Test

\begin{tabular}{|l|r|r|}
\hline & \multicolumn{1}{|c|}{ CR } & \multicolumn{1}{c|}{ DER } \\
\hline CR & 1 & $\mathbf{- 0 . 4 6 9 3 9}$ \\
\hline DER & $\mathbf{- 0 . 4 6 9 3 9}$ & 1 \\
\hline
\end{tabular}

Source: Data processed with eviews 10, 2020 
The results of the tests carried out show that the value of the correlation coefficient between independent variable current rati (CR) and debt to equity ratio (DER) has a value of $<0.85$ of 0.46939 , so that the regression model used does not occur multicollinearity problems.

\section{Hypothesis testing \\ a. T Uji test}

The t-test basically has the aim of showing how far the influence of an explanatory or independent variable individually in explain the independent variables. The significance level used in this study was $0.05(\alpha=5 \%)$. The acceptance and rejection of the hypothesis will be carried out with the following criteria:

a. If the prob value. greater than 0.05 and $t$ count $<t$ table, then the hypothesis is rejected.

b. If the probability value is less than 0.05 and $t$ count $>t$ table, then the hypothesis is accepted.

The $t$ table value at a significance level of 0.05 and degrees of freedom (df) is $\mathrm{df}=\mathrm{nk}-1=$ $30-2-1=27$, so that the $t$ table value is 2.052 . The results of the $t$ test can be seen in the following table.

Table 4.6 T. Test Results

\begin{tabular}{|c|c|c|c|c|}
\hline Variable & Coefficient & Std. Error & t-Statistic & Prob. \\
\hline$C$ & 0.014596 & 0.037623 & 0.387963 & 0.7011 \\
\hline $\mathrm{CR}$ & 0.009607 & 0.008677 & 1.107223 & 0.2780 \\
\hline DER & 0.032852 & 0.010614 & 3.095135 & 0.0045 \\
\hline
\end{tabular}

Source: Data processed with eviews 10, 2020

Based on the test results in the table above, it can be concluded that the hypothesis testing of each independent variable on the dependent variable is as follows:

a. H1 = There is an effect of Current Ratio (CR) on Stock Prices in Metal \& Similar Companies listed on the Indonesia Stock Exchange

Prob value. $t$ count of the independent variable current ratio as big as 0.2780 greater than 0.05 and the value of $\mathrm{t}$ arithmetic $<\mathrm{t}$ table of $1.107223>2.052$ which indicates that the independent variable current ratio no effect on stock prices. It means There is no effect of Current Ratio (CR) on Share Prices in Metal \& Similar Companies listed on the Indonesia Stock Exchange. The conclusion in this study is to reject $\mathrm{H} 1$.

b. $\mathrm{H} 2=$ There is an effect of Debt to Equity Ratio (DER) on Stock Prices in Metal \& Similar Companies listed on the Indonesia Stock Exchange

Prob value. $t$ count of the independent variablesdebt to equity ratio as big as 0.0045 which is smaller than 0.05 and the value of $t$ count $>t$ table is $3.095135>2.052$ which indicates that the independent variable debt to equity ratio effect on stock prices. It meansthere is an effect of Debt to Equity Ratio (DER) on stock prices in metal \& similar companies listed on the Indonesia Stock Exchange. The conclusion in this study is to accept H2.

\section{b. F Uji test}

The F statistical test was carried out to see whether all the independent variables included in the model were feasible to explain the dependent variable. The $\mathrm{f}$ test is also used to prove whether together all the independent variables arecurrent ratio (CR) and debt to equity ratio (DER) has an influence on the dependent variable, namely share price (PER).The criteria for testing carried out are:

a) If the value of Prob. (0.05) and F count > F table, then $\mathrm{Ha}$ is accepted, namely the independent variable has a simultaneous effect on the dependent variable.

b) If the value of Prob (0.05) and F count < F table, then HO is accepted, that is, the independent variable has no simultaneous effect on the dependent variable.. 
The $\mathrm{F}$ table value at a significance level of 0.05 and degrees of freedom $(\mathrm{df})$ is $\mathrm{df}=\mathrm{nk}-1=$ $30-2-1=27$, so that the $\mathrm{f}$ table value is 3.35 . The results of the $\mathrm{f}$ test in this study can be seen in the following table:

\begin{tabular}{|c|c|c|c|}
\hline & & & \\
\hline R-squared & 0.264967 & Mean dependent var & 0.087795 \\
\hline Adjusted R-squared & 0.210520 & SD dependent var & 0.090069 \\
\hline $\mathrm{SE}$ of regression & 0.080029 & Akaike info criterion & -2.118217 \\
\hline Sum squared resid & 0.172925 & Schwarz criterion & -1.978097 \\
\hline Likelihood logs & 34.77325 & Hannan Quinn Criter. & -2.073391 \\
\hline F-statistics & 4.866521 & Durbin-Watson stat & 2.378399 \\
\hline Prob(F-statistic) & 0.015673 & & \\
\hline
\end{tabular}

Based on the results of statistical tests in the table above, it is known that:

H3 : There is an effect of Current Ratio (CR) and Debt to Equity Ratio (DER) on Stock Prices of Metal \& Similar Companies listed on the Indonesia Stock Exchange.

Prob value. $F$ (Statistics) in the table above is 0.015673 smaller than the 0.05 significance level and the calculated $\mathrm{F}$ value $>\mathrm{f}$ table is $4.866521>3.35$, so it can be concluded that the estimated regression model can be used to explain the effect of independent variable relationship current ratio (CR) and debt to equity ratio (DER) to the dependent variable share price (PER), in other words There is an effect of Current Ratio (CR) and Debt to Equity Ratio (DER) on Stock Prices in Metal \& Similar Companies listed on the Indonesia Stock Exchange. The conclusion in this study is to accept the hypothesis $\mathrm{H} 3$.

\section{c. Coefficient of Determination Test}

The coefficient of determination (R2) aims to see how much the independent variable's ability to explain the dependent variable is seen through adjusted $\mathrm{R}^{2}$. The value of the coefficient of determination is zero and one. A small value of R2 means that the ability of the independent variables in explaining the variation of the dependent variable is very limited. The results of the coefficient of determination can be seen in the following table:

\begin{tabular}{lcll}
\multicolumn{4}{c}{ Table 4.8 Coefficient of Determination (R2) } \\
R-squared & $\mathbf{0 . 2 6 4 9 6 7}$ & Mean dependent var & 0.087795 \\
Adjusted R-squared & 0.210520 & SD dependent var & 0.090069 \\
SE of regression & 0.080029 & Akaike info criterion & -2.118217 \\
Sum squared resid & 0.172925 & Schwarz criterion & -1.978097 \\
Likelihood logs & 34.77325 & Hannan Quinn Criter. & -2.073391 \\
F-statistics & 4.866521 & Durbin-Watson stat & 2.378399 \\
Prob(F-statistic) & 0.015673 & & \\
Source: Data processed with eviews & 10,2020 &
\end{tabular}

Based on the test results, the value obtained from the coefficient of determination $r$ square in the table above is 0.264967 , this matter shows that the proportion of influence independent variable current ratio (CR) and debt to equity ratio (DER) on the dependent variable of stock price (PER) by 26.5 percent while the remaining 73.5 percent $(100-26.5$ percent $)$ is influenced by other variables that are not in the regression model. 


\subsection{DISCUSSION}

\subsubsection{Effect of Current Ratio on Stock Price}

Based on the results of research on Current Ratio to Stock Prices using eviews on Metal and Similar companies listed on the Indonesian Stock Exchange. This shows that the Current Ratio partially has no effect on the stock price of metal and similar companies listed on the Indonesia Stock Exchange for the 2014-2018 period. The results of this study support researchers based on by Chandra and Taruli (2017) which states that partially the Current Ratio has no effect and is not significant to the Stock Price.

In line with the thesis research by Febianto (2015) it can be said that the current ratio has no significant effect on stock prices.

And not in line with research conducted by Primary and Erawati (2014)Current Ratio has a significant and positive effect on stock prices. The higher this ratio, the company is considered to be more able to pay off its short-term obligations so that it will attract investors to buy the company's shares and will increase the share price.

\subsubsection{The Effect of Debt to Equity Ratio on Stock Prices}

Based on the results of the Debt to Equity Ratio research on Stock Prices using eviews on Metal and Similar companies listed on the Indonesian Stock Exchange. This shows that the Debt to Equity Ratio partially affects the stock price of metal and similar companies listed on the Indonesia Stock Exchange for the 2014-2018 period. The results of this study support researchers by Munira et al., (2018) which is represented by the Debt to Equity Ratio has a significant effect on stock prices.

And it is not in line with the previous thesis research conducted by Selviyana (2018)which states that the Debt to Equity Ratio has no effect on stock prices. Thus, it can be concluded that the higher the Debt to Equity Ratio (DER), the lower the stock price and conversely the lower the Debt to Equity Ratio (DER), the higher the stock price.

The greater the Debt to Equity Ratio (DER) indicates the greater the cost of debt that must be paid by the company so that profitability decreases. Companies with high debt will go bankrupt, as a result investors will avoid stocks with low profit values which will ultimately lower stock prices which impact on stock prices, high DER causes stock prices to decline.

\subsubsection{Effect of Current Ratio and Debt to Equity Ratio on Stock Prices}

Based on the research results Current Ratio and Debt to Equity Ratio to Stock Prices using eviews on metal and similar companies listed on the Indonesian stock exchange. This explains the effect of the variable Current Ratio and Debt to Equity Ratio on the dependent variable of Stock Price (PER), in other words there is an effect of Current Ratio and Debt to Equity Ratio on Stock Prices of Metal \& Similar companies listed on the Indonesia Stock Exchange.

HaThe results of this study are in line with the results of the studyNovita Sari it is known that CR, DER, ROA and ROE simultaneously have a significant effect on stock prices.

\section{CONCLUSION}

Based on the results of the research and discussion that have been stated previously, it can be concluded from research on the effect of the Current Ratio (CR) and Debt to Equity Ratio (DER) on stock prices in Metal and Similar Companies listed on the Indonesia Stock Exchange for the period 2014-2018 with sample of 6 companies. Current ratio no effect on stock prices. Debt to equity ratio effect on stock prices. Current Ratio and Debt to Equity Ratio to Stock Pricesimultaneously show that the estimated regression model can be used to explain Effect of Current Ratio (CR) and Debt to Equity Ratio (DER) on Stock Prices in Metal \& Similar Companies listed on the Indonesia Stock Exchange. 
Effect Of Current Ratio And Debt To Equity Ratio On Stock Prices On Registered Metal And Similar Companies On The Indonesia Stock Exchange

DOI: $10.54443 /$ ijebas.v1i2.77

The suggestions that can be given in this research are as follows: Companies should be able to maximize the company's own assets and capital in increasing company profits, in order to increase confidence in investors in the form of company performance results and financial statements. For further researchers, it is better to use more samples with more diverse characteristics from various sectors and extend the research period and add independent variables that are still based on financial statements other than those used in this study by remaining based on previous studies. Pay attention to external factors that can affect the company's financial statements. So that it can add analysis of new findings.

\section{REFERENCES}

Adminami, A. (2020). Mengetahui Rumus Current Ratio dan Penjelasannya Lengkap. http://rumusrumus.com/rumus-current-ratio/

Arseto, D. D., \& Jufrizen, J. (2018). Pengaruh Return On Asset dan Current Ratio Terhadap Dividen Payout Ratio Dengan Firm Size Sebagai Variabel Moderating. Maneggio: Jurnal Ilmiah Magister Manajemen, 1(1), 15-30.

Asmirantho, E., \& Yuliawati, E. (2015). Pengaruh Dividen Per Share (DPS), Dividen Payout Ratio (DPR), Price To Book Value (PBV), Debt To Equity Ratio (DER), Net Profit Margin (NPM) dan Return On Asset (ROA) Terhadap Harga Saham Pada Pendahuluan Harga saham yang mengalami kenaikan. Jurnal Ilmiah Akuntansi Fakultas Ekonomi, 1(2), 103-117.

Baridwan, Z. (2010). Sistem Akuntansi Penyusunan Prosedur dan Metode (Lima). BPFE.

Chandra, S., \& Taruli, D. (2017). Analysis Of The Influence Of Current Ratio (CR), Debt To Equity Ratio (DER), Return n Equity (ROE) and Price Earning Ratio (PER) On The Share Prices Of Mining Companies Listed On Indonesia Stock Exchange During 2012-2015. KURS, 2(2), 128-137.

Fahmi, I. (2015). Analisis Laporan Keuangan (p. 136). PT. Raja Grafindo Persada.

Febianto, A. (2015). Pengaruh Return On Asset, Current Ratio, Debt to Equity Ratio, Dividen, Laba Bersih dan Dividend Payout Ratio terhadap Harga Saham Syariah Pada Perusahaan Yang Terdaftar di Jakarta Islamic Index Periode 2019-2014.

Hantono, H. (2015). Pengaruh Current Ratio Dan Debt To Equity Ratio Terhadap Profitabilitas Pada Perusahaan Manufaktur Sektor Logam Dan Sejenisnya Yang Terdaftar Di Bursa Efek Indonesia Periode 2009 - 2013. Jurnal Wira Ekonomi Mikroskil, 5(1), 21-30.

Harahap, S. S. (2010). Analisis Kritis Atas Laporan Keuangan (Satu). Rajawali Pers.

Hasibuan, J. S. (2017). Pengaruh Debt to Asset Ratio dan Debt to Equity Ratio Terhadap Return On Asset Pada PT. Perkebunan Nusantara III (Persero) Medan. Jurnal Keuangan Dan Bisnis, 9(1), 58-70.

Kasmir, K. (2013). Analisis Laporan Keuangan. Raja Grafindo Persada.

Kasmir, K. (2014). Bank dan Lembaga Keuangan Lainnya. PT. Raja Grafindo.

Munira, M., Merawati, E. E., \& Astuti, S. B. (2018). Pengaruh ROE dan DER Terhadap Harga Saham Perusahaan Kertas di Bursa Efek Indonesia. Journal of Applied Business and Economics, 4(3), 191-205.

Novitasari, R. (n.d.). Pengaruh Current Ratio (CR), Debt to Equity Ratio (DER), Return On Assets (ROA) dan Return On Equity (ROE) Terhadap Harga Saham (Studi pada Perusahaan Sub Sektor Telekomunikasi yang Terdaftar di Bursa Efek Indonesia Periode 2013-2016).

Nur Ilham, R. ., Arliansyah, A., Juanda, R., Multazam, M. ., \& Saifanur, A. . (2021). RELATHIONSIP BETWEEN MONEY VELOCITY AND INFLATION TO INCREASING STOCK INVESTMENT RETURN: EFFECTIVE STRATEGIC BY JAKARTA AUTOMATED TRADING SYSTEM NEXT GENERATION (JATS-NG) PLATFORM. International Journal of Economic, Business, Accounting, Agriculture Management and Sharia Administration (IJEBAS), 1(1), 87-92. https://doi.org/10.54443/ijebas.v1i1.27 


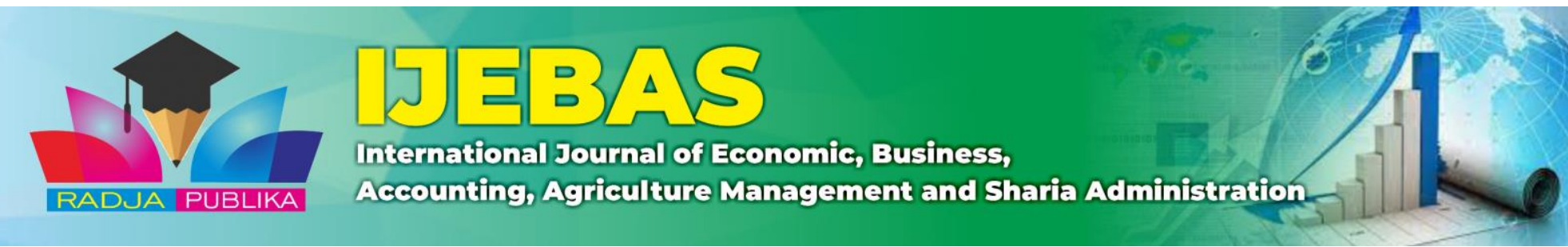

Pratama, A., \& Erawati, T. (2014). Pengaruh Current Ratio, Debt To Equity Ratio, Return On Equity, Net Profit Margin dan Earning Per Share (Study Kasus Pada Perusahaan Manufaktur Yang Terdaftar Di Bursa Efek Indonesia Periode 2008-2011). Jurnal Akuntansi, 2(1), 1-10. https://doi.org/10.24964/ja.v2i1.20

Putri, D. E., Ilham, R. N., Sinurat, M., Lilinesia, L., \& Saragih, M. M. S. (2021). Analysis of Potential and Risks Investing in Financial Instruments and Digital Cryptocurrency Assets during the Covid-19 Pandemic. Jurnal SEKURITAS (Saham, Ekonomi, Keuangan dan Investasi), 5(1), 1-12.

Putri, L. P. (2015). Pengaruh Profitabilitas Terhadap Harga Saham Pada Perusahaan Pertambangan Batubara di Indonesia. Jurnal Ilmiah Manajemen Dan Bisnis, 16(02), 49-59. https://doi.org/10.1145/3132847.3132886

Raha, M. (2010). Go public. Print Professional, 46(2), 20-24. https://doi.org/10.12968/nuwa.2018.9.37

Rambe, M. F., Gunawan, A., Julita, R. P., Gultom, D. K., \& Wahyuni, S. F. (2017). Pengantar Manajemen Keuangan. Citapustaka Media.

Rasio Likuiditas. (2020). Mastah Bisnis. http://mastahbisnis.com/rasio-likuiditas/

Selviyana, L. F. (2018). Pengaruh Return On Asset (ROA), Return On Equity (ROE) dan Debt to Equity Ratio (DER) Terhadap Harga Saham Syariah Perusahaan Yang Terdaftar di Jakarya Islamic Index (JII).

Siregar, Q. R., \& Farisi, S. (2018). Pengaruh Return On Assets Dan Earning Per Share Terhadap Harga Saham. Maneggio: Jurnal Ilmiah Magister Manajemen, 1(1), 81-89. 
Effect Of Current Ratio And Debt To Equity Ratio On Stock Prices On Registered Metal And Similar Companies On The Indonesia Stock Exchange

DOI: $10.54443 /$ ijebas.v1i2.77 